\title{
LEGAL DYNAMICS AND IMPLEMENTATION PROBLEMS OF JUDICIAL REVIEW AUTHORITY IN THE SUPREME COURT
}

\author{
Janpatar Simamora \\ Faculty of Law, Universitas HKBP Nommensen, Medan \\ E-mail: patarmora@yahoo.com
}

\begin{abstract}
This paper is intended to find out how the development of settings as well as problems of implementation of judicial review authority of the Supreme Court. Based on the development the settings, the Supreme Court has long had the judicial review authority. Correspondingly, there is a development setting judicial review authority through a number of regulations. However, in practice, there are a number of problems. First, in terms of regulation, not reflecting the comprehensive procedural law. Second, in terms of judicial review case handling process, has not shown that there is transparency. Therefore, it should be repair, so that the implementation of such authorities take place optimally and able to offset the reputation of the Court.
\end{abstract}

Keywords: judicial review, judicial institutions, Supreme Court

\begin{abstract}
Abstrak
Tulisan ini dimaksudkan untuk mengetahui bagaimana sesungguhnya dinamika pengaturan serta problem penerapan kewenangan judicial review Mahkamah Agung. Didasarkan pada dinamika pengaturannya, Mahkamah Agung sudah lama memiliki kewenangan judicial review. Sejalan dengan itu, terjadi dinamika pengaturan kewenangan judicial review melalui sejumlah regulasi. Namun dalam pelaksanaannya, terdapat sejumlah problem. Pertama, dari segi regulasi, belum mencerminkan adanya hukum acara yang komprehensif terkait kewenangan judicial review. Kedua, dari segi proses penanganan perkara judicial review, belum menunjukkan adanya transparansi. Oleh sebab itu, Mahkamah Agung perlu melakukan pembenahan, sehingga pelaksanaan kewenangan judicial review di Mahkamah Agung dapat berjalan baik dan mampu mengimbangi reputasi Mahakamah Konstitusi.
\end{abstract}

Kata kunci: judicial review, lembaga peradilan, Mahkamah Agung

\section{Introduction}

Dynamics of constitution of Indonesia after reformation era is undergoing rapid changes as passing of constitutional reformation. ${ }^{1}$ One of the dynamics of constitution form is the attempt to institutionalize authority to examine legislation by the Judiciary. Through the testing authority, judicial institution authorized to conduct testing on a legislation to the higher level legislation and to ensure that the executive ac- tion through the established regulations is completely in accordance with the law. ${ }^{2}$

The authority is more well-known as the judicial review authority which is an important element of modern democracy theory and the rule of law. ${ }^{3}$ The existence of judicial review authority makes the judiciary have the power to make a strong verdict related to the validity of a legislation, where decision shall be respected

2 Amy Street, Judicial Review and the Rule of Law: Who is in Control?, London: The Constitution Society, 2013, page 12.

3 Michael B. Wise, “Judicial Review and Its Politicization in Central America: Guatemala, Costa Rica, and Constitutional Limits on Presidential Candidates", Santa Clara Journal of International Law, Vol. 7 Issue 2, 2010, Santa Clara: School of Law Santa Clara University, page 147. 
by all parties, including branches of government authority. ${ }^{4}$

Constitutional basic of judicial review authority in Indonesia, is regulated in Article $24 \mathrm{~A}$ paragraph (1) and Article 24 C paragraph (1) Constitution of Republic of Indonesia of 1945. Article 24A paragraph (1) governs authority of Supreme Court (MA) in testing legislation under legislation (the Act), to the Act. Furthermore, Article 24 C paragraph (1) governs the authority of the Constitutional Court (MK) to hear at the first and last stage in which verdict is final to test the Act towards Constitution.

Seen from the pattern of the setting, it can be concluded that the test process of legislation in Indonesia is conducted by two institutions, those are Supreme Court and Constitutional Court with a different test objects. Supreme Court is authorized to conduct judicial review with the object of testing legislation under the Act, to the Act. Meanwhile Constitutional Court has authority of judicial review with the object reviewing legislation to the Constitution.

Based on the object of testing from both judiciary, Supreme Court actually has a wider testing object, which is the entire legislation under the Law. However, based on the facts, the most prominent judicial review process is actually judicial review process run by Constitutional Court (MK). In fact, the presence of Constitutional Court is relatively new, because it is born since the third amendment of 1945 Constitution in 2001. ${ }^{5}$

Indeed, sorting of judicial review authority in two different state institutions is not exactly known until now. Probably, this is done due to there are two institutions that run the judicial power in Indonesia, which are Supreme Court and Constitutional Court. The framers of the 1945 constitution amendment seem likely to divide the judicial review authority between the two judicative institution equitably.

\footnotetext{
Alon Harel and Tsvi Kahana, "The Easy Core Case for Judicial Review”, Journal of Legal Analysis, Vol. 2 No. 1, Spring 2010, Oxford: Oxford University Press, page 230.

5 Janpatar Simamora, "Comparison of Constitutional Court Authority Between Indonesia and South Korea", Jurnal Dinamika Hukum, Vol. 15 No. 3, September 2015, Purwokerto: Faculty of Law Universitas Jenderal Soedirman, page 332 .
}

In order to follow up both institution's constitutional authority on judicial review and in attempt to facilitate the operationalization of their authority, Supreme Court and Constitutional Court establish advanced regulation in their respective institutions' level. Constitutonal Court establishes Regulation Number 6/ PMK/2005 concerning Guidelines on Proceedings in Case of Testing Legislation. Meanwhile, Supreme Court has established and revised the regulations related to its judicial review authority several times and the last is the Supreme Court Regulation Number 1 Year 2011 concerning the Rights of the Material Test.

Further discussion in this paper is related to the dynamics of the settings of judicial review authority possessed by Supreme Court and its implementation problems. This is based on consideration that Supreme Court has made several changes to the regulations governing the operationalization of Supreme Court authority on judicial review. Change by change of the operational regulation needs to have further research as well as any problems occured at the level of the implementation.

Surely, change by change on a number of Supreme Court regulations are intended to maximize the implementation of the judicial review authority possessed by Supreme Court. Along with it, it becomes very important to be known and analyzed about how the practice of judicial review authority by the Supreme Court over the time.

\section{Discussion}

\section{A Brief History of Supreme Court Judicial Re- view Authority}

Judicial review authority is the right owned by the judiciary to test the legislation whether it is contrary or not to the regulations of a higher order. ${ }^{6}$ In the United States, judicial review authority is considered as the natural authority of the judiciary, even before being

\footnotetext{
Janpatar Simamora, "Considering Centralization Of Judicial Review Authority In Indonesia Constitutional System", IOSR Journal of Humanities And Social Science (IOSR-JHSS), Shastri Nagar, Ghaziabad, UP, Vol. 21 Issue 2, Ver. V (Feb. 2016), India: International Organization of Scientific Research, page 28.
} 
adopted by the Constitution of United States. It is said because the American Constitution did not initially regulate judicial review authority of federal courts explicitly. ${ }^{7}$

Through judicial review authority, the judiciary may contribute to prevent the abuse of power through the legislation established by the government. ${ }^{8}$ In some countries, judicial review authority is run by a separated institution called constitutional court. The court can be seen in Germany, Italy, Austria, Spain and Belgium. Based on the the authority to cancel a legal product that established by the legislative, then Hans Kelsen describes the authority of constitutional court as a negative legislators. ${ }^{9}$ However, Hans Kelsen differentiated how parliament and constitutional court made law, which parliament as positive legislators made laws directly based on the authority, while constitutional court as a negative legislators made laws through cancellation process. ${ }^{10}$

Based on the history of Indonesia's constitution, attempts to institutionalize judicial review authority through Supreme Court had been long prominent since the preparation of Indonesian independence in 1945. But in that time, the institutionalization of authority was limited to the right of material test which was just one side of the scope of judicial review authority. Since the beginning of the formation of the 1945 Constitution, proposal of authority of judicial review to be given to the judiciary had been surfaced. Through The Investigating Committee for Preparatory Work for Indonesian Independence (BPUPKI) meeting on July 1945, proposal of establishment of institutions that

William Michael Treanor, "Judicial Review Before Marbury”, Stanford Law Review, Vol. 58, November 2005, Stanford, CA: The Stanford Law School, page 460.

8 David S. Law, "A Theory of Judicial Power and Judicial Review", The Georgetown Law Journal, Vol. 97, 2009, Washington DC: Georgetown Law, page 727.

9 J. Uzman, T. Barkhuysen \& M.L. van Emmerik, "The Dutch Supreme Court: A Reluctant Positive Legislator?", Electronic Journal of Comparative Law, Vol. 14. Issue 3, December 2010, The Netherlands: the Law Faculties of Maastricht, Tilburg and Utrecht, page 1.

10 Alec Stone Sweet, "The Politics of Constitutional Review in France and Europe", International Journal of Constitutional Law, Vol. 5 No. 1, Januari 2007, Oxford: Oxford University Press and New York University School of Law, page 83 . had authority to do judicial review was strengthened.

However, the proposal had not been accommodated because of various considerations. One of the reason was that Indonesia didn't have any legal experts, especially constitutional law experts to run the authority. Based on these considerations, during the enactment of the 1945 Constitution, there were no judicial review authority. Even the judicial review authority that was discussed was no longer discussed further to be immediately implemented in Indonesia.

After the enactment of the Constitution of Republic of United States of Indonesia (RIS) 1949; known as RIS Constitution of 1949, attempted to institutionalize judicial review authority resurfaced. Even for the first time, Supreme Court obtained constitutional authority of judicial review through the RIS Constitution of 1949. Through Article 156 paragraph (1) of the RIS Constitution states that if Supreme Court or other courts that adjudicate in civil cases considers that a rule of constitutional or law of a section area is contrary to the constitution, then the decision of the judiciary as well, is that the provision explicitly not according to the constitution.

Furthermore, in Article 156 paragraph (2) states that the Supreme Court also has the authority to declare that a provision in the constitutional regulations or in Law are not according to the constitution, as long as there is request for it, either by the Government of Republic of United States of Indonesia (RIS) or based on the application letter submitted by or on behalf of the Attorney General at the Supreme Court as well as by state and also by the prosecutor at the high court of the state. Under these conditions, Supreme Court has the authority to do judicial review, but only limited in reviewing the state legislation to the constitution.

In the next development, which was the period of enactment of Provisional Constitution of 1950, the judicial review authority was abolished. This was in line with the change in shape of the country, from the previous shape which was federation under the RIS constitution of 
1949 became united state in 1950 Provisional Constitution. After the enactment of Presidential Decree of July 5, 1959 confirmed that the constitution of Indonesia is back to 1945 constitution, the idea of judicial review authority reappeared. The idea was ever delivered by Sri Soemantri on 1968, but failed to be realized.

Furthermore, through the promulgation of Law Number 14 Year 1970 concerning the Main Principles of Judicial Power, judicial review authority was accommodated again. Through Article 26 paragraph (1) affirmed that Supreme Court has authority to outlaw all the legislation from the lower level of the Law on the reason it is contrary to the higher legislation. Then in the next paragraph emphasized that the decision on the illegality statement of the legislation can be taken in connection with the examination in an appeal and revocation of the legislation that declared illegitimate, carried out by the relevant agencies.

Referring to the content of Article 26, Supreme Court is authorized to conduct judicial review, but is confined to the legislation under the Law to the Law. Meanwhile authority of judicial review of law to Constitution is not yet accomodated. hereafter, although Law No. 14 Year 1985 On Supreme Court had been established, but the concept of judicial review authority as stipulated in Article 31 of the law was no different to provisions stipulated in Article 26 of Law No. 14 Year 1970.

After the passing of the 1945 constitution amendment, judicial review authority is arranged in such a way in the constitution. Through Article 24A Paragraph (1), Supreme Court authority to conduct judicial review is reaffirmed, but still remain in the old concept, which is limited in reviewing regulations under the Law to the Law.

\section{Dynamics of Supreme Court Regulation On Ju- dicial Review}

As outlined previously that the history of implementing the authority of judicial review by the Supreme Court has been longstanding through a number of era. Correspondingly, the Supreme Court has issued a number of regula- tions in the form of Supreme Court regulations related to the implementation of the judicial review authority several times. The number of regulations mentioned, is started from the ratification of Supreme Court Regulation No. 1 Year 1993 concerning the Rights of the Material Testing.

There are two main points behind the enactment of the Supreme Court Regulation Number 1 Year 1993. First, that under the provision of Article 11 (4) MPR Decree No. III/ MPR/1978, Law Number 14 Year 1970 article 26 and Law Number 14 Year 1985 article 31, Supreme Court has the authority to conduct material testing to the regulations under the Law. Second, until the issuance of the regulations mentioned, the existence of a procedural law as operational guidelines of Supreme Court in performing its judicial review authority had not been found. Both consideration are then used as the basis in setting the Supreme Court Regulation Number 1 Year 1993.

Furthermore, in the further development of Supreme Court Regulation Number 1 Year 1993, was replaced through Supreme Court Regulation Number 1 Year 1999 concerning the Rights of the Material Testing and continued with the establishment of Supreme Court Regulation Number 1 of 2004 concerning the Rights of the Material Testing. The basic consideration of the enactment of Supreme Court Number 1 Year 2004 is not separated from attempts to synchronize the Law Number 4 Year 2004 on Judicial Power and Law Number5 Year 2004 concerning Supreme Court.

One of the important points to be studied in the Supreme Court Regulation Number 1 Year 2004 is related to the provision in Chapter II about the Procedure for Submission of Objection Petition, particularly Article 2 paragraph (4). Based on the article mentioned, it is emphasized that the petition of objection in the case of judicial review in the Supreme Court shall be filed within 180 days since the enactment of the legislation concerned.

Based on the provision mentioned, an application for judicial review case in the Supreme Court can only be filed within 180 days 
after the legislation that became the object of judicial review in the Supreme Court set by the institution that has the authority to set it. This provision is aimed to limit a legislation that could be made as the object of testing in the judicial review case in the Supreme Court. In consequence, even if there is a conflict of norms in a legislation under the Law to the Law, but if the case of judicial review is filed beyond the limit of 180 days since the legislation approved, Supreme Court will reject the case certainly.

Furthermore, Supreme Court Regulation Number 1 Year 2004 is no longer applicable as the Supreme Court Regulation Number 1 Year 2011 concerning Judicial Material is enacted. The process of formation of Supreme Court regulation is based on considerations to abolish the time limit of petition which is previously restricted in 180 days after the enactment of the law. Limitation of submission of application is considerably not appropriate to be applied, especially for a general regulation (Regeling). Moreover, this kind of regulation model is less appropriate when is linked to the efforts to achieve the living law.

Reasons to limit the legislation under the Law which can be done by judicial review in Supreme Court in terms of its legalization is not exactly known. Whether these things are done in order to limit the accumulation of judicial review cases or because of any other consideration. In addition, it should be noted that the imposition of such restrictions would only narrow the space for those who seek for justice to question about the legislation through judicial review case in Supreme Court.

As an illustration, for example, what if in the beginning of the enactment of a regulation under the Law, the presence of legal issues has not been found. It means, it will not necessarily be a concern over the imposition of a law and regulation within 180 days after the enactment of the law. It could be disadvantage or problem over the imposition of a law and regulation under the Law and would arise after more than 180 days since the legislation approved and validated.
If the this kind of condition happened, problems related with what legal actions can be done to question the legislation considered problematic would appear. This then makes the restriction model become decent to be discussed. Therefore, the enactment of Supreme Court Regulation Number 1 Year 2011 can be defined as a step to optimize the implementation of the judicial review authority of Supreme Court.

\section{Problem of Implementation of Judicial Review Authority in Supreme Court}

During the time, the implementation of judicial review authority in Supreme Court takes less public attention. These conditions can not be separated from the legal culture that had been developed over where the lack of public trust in the judicial process run by Supreme Court for not being transparent and requires no small cost. It can be seen in the lack of judicial review cases in the Supreme Court. Different conditions would occur in judicial review case in the Constitutional Court. Supposedly, viewed from the quantity of the test object, the implementation of judicial review authority in Supreme Court will be more booming than judicial review in Constitutional Court.

Based on these conditions, it is very urgent to know various issues surrounding the implementation of judicial review authority of Supreme Court, so that a further improvements can be made. Through the improvement mentioned, Supreme Court can contribute maximally in carrying the judicial review authority. Furthermore, there are a number of problems related to the implementation of judicial review authority of Supreme Court. The problem mentioned can be categorized into two parts.

First, in terms of regulation related to the basic application for those who feel aggrieved over the enactment of a legislation under the Law. As emphasized in Article 31A paragraph (1) letter b Law Number 3 Year 2009 concerning the Second Amendment to Law Number 14 Year 1985 concerning Supreme Court, that the basis of the petition which shall be described in the case of judicial review in Supreme Court are: 
184 Jurnal Dinamika Hukum Vol. 16 No. 2, May 2016

1. The substance of paragraphs, articles and/ or parts of the legislation under the law are considerably contrary to the higher legislation; and/or

2. Establishment of legislation does not meet the applicable provisions.

The basic consideration in the first part is the basic material test, while the basic considerations on the second part is the basic formal test. In the provisions of Article 31 paragraph (2) of Law Number 5 Year 2004 concerning The First Amendment to the Law Number 14 Year 1985 regarding Supreme Court stated that the Supreme Court declares invalid to the legislation under the Law on the reasons that it is contrary to the higher legislation or the establishment does not meet the applicable provisions.

Under these provisions, if then in a legislation is found a substance of paragraphs, articles, and/or part of a legislation under the Law are contrary to the Law, Supreme Court declares that the legislation is invalid and does not have strong legal force. The latter problem is, what if a judicial review process conducted by Supreme Court only discovers the existence of a paragraph or a chapter conflicting with higher law.

Referring to such provisions, it is clear that Supreme Court will give decision that declares the whole legislation is invalid and does not have binding legal force. This kind case handlings model is not effective because their material testing actually enforce judgments as a whole and not by passage, chapter, or other part that is totally contrary to the higher legislation.

This is very different from the implementation of judicial review authority of the Constitutional Court where the verdict of judicial review case is possibly done by sorting paragraphs, chapters or sections that are considered contrary to the 1945 Constitution. Referring to the provisions of Article 57 Law Number 8 Year 2011 concerning Constitutional Court, states that:

Paragraph (1): Verdict of Constitutional Court which states that the substance of paragraphs, articles, and/or parts of the law are contrary to Constitution of Re- public of Indonesia of 1945, the substance of paragraphs, articles, and/or parts of the Law does not have strong legal force.

Paragraph (2): Verdict of Constitutional Court which states that the establishment of the Law does not meet the provisions of establishment of the Law under Constitution of Repucblic of Indonesia of 1945, the Law does not have strong legal force.

The first paragraph describes the verdict of Constitutional Court regarding to the material examination of a Law to the 1945 Constitution. The paragraph (2) describes the verdict of Constitutional Court in the case of formal review of a legislation based on the Law the establishment procedure. Based on the judicial review system in the material sense, if a substance of paragraphs, articles, and/or a certain part of a rule contrary to the higher legislation, the object canceled is only the substance of paragraphs, articles, and/or a particular part of a regulation which proved contrary to the higher legislation. The judicial review in the formal sense is that if the procedure of legislation establishment does not meet the applicable provisions, the regulation will be declared invalid as a whole.

Moreover, the reasons which state a legislation under the Law by the Supreme Court invalid is possible in consideration that the material content is contrary to the higher legislation (material test) and the establishment does not meet the applicable requirements (formal test). Though, special rules for the guidelines on the proceedings in the case of judicial review, either formal and substantive is not found. Supreme Court only has guidelines in proceedings the material test, whereas in the case of formal test has not yet formed. These conditions require further improvement in order to optimize Supreme Court judicial review authority.

Second, in terms of the structure of case handling process, where the structure of judicial review case handling in Supreme Court is still not transparent, and even tend to be 
closed. ${ }^{11}$ These conditions in turn make the litigants in the judicial review case feeling hard to understand how exact stages of judicial review case handlings and monitoring the petition filed. The lack of transparency of judicial review case handling almost occurred throughout the process, from the filing of the case until the verdict.

Unlike the judicial review process conducted by Constitutional Court, the whole process of handling judicial review cases must be transparent and can be monitored directly by each party. Supreme Court should be able to make it as a reference in order to establish judicial review case handling process better. Transparency in handling cases by the judiciary in the end will make the judiciary trusted. As well the quantity of judicial review cases in the Constitutional Court are more than the Supreme Court, even though there are more case objects in Supreme Court. For example, in 2014, the Constitutional Court received 140 judicial review cases, ${ }^{12}$ while Supreme Court only received 83 cases in the same year. ${ }^{13}$ Both issues are supposed to be immediately improved so Supreme Court can gained the trust of the public maximally on implementing its authority. Moreover, the judges at Supreme Court as well as the whole range of employees must show their high intregity and not easily affected by a variety of bribery that could potentially led the Supreme Court decision become not objective. Through such improvements, inevitably Supreme Court will gain full trust of those who seek for justice in this country.

Supreme Court as one of the executors of the judicial authoritiy should be able to offset the reputation of Constitutional Court which is so good, so Supreme Court are able to get achievements in accordance with the portion of

11 Abdul Azis Nasihuddin, "Implementasi Hak Uji Materiil Peraturan Daerah Kabupaten/Kota oleh Mahkamah Agung dan Pengaruhnya Terhadap Pemberdayaan Daerah", Jurnal Dinamika Hukum, Vol. 13 No. 3, September 2013, Purwokerto: Faculty of Law Universitas Jenderal Soedirman, page 436

12 MK RI, "Rekapitulasi Perkara Pengujian Undang-Undang", http://www.mahkamahkonstitusi.go.id/index. php?page $=$ web. RekapPUU\&menu $=5$, accessed on June 20, 2016.

13 MA RI, Laporan Tahunan MA RI 2014, page 24. the authority possessed. Another important thing to be improved is related to the applicable court fees in Supreme Court and the plot of bureaucracy for settling the disputes which still loaded with old paradigms, yet it does not fully reflect the accommodation of the principles of good justice, which are fast, simple and inexpensive.

\section{Conclusion}

Settings of judicial review authority of Supreme Court (MA) have experienced dynamics regulation which is so long. It can be seen from the revisions of the regulations governing judicial review authority of Supreme Court (MA). However, until now, implementation of authority is still hampered by a number of problems. First, in terms of regulation, not reflecting the comprehensive procedural law. Second, in terms of judicial review case handling process, has not shown that there is transparency as a form of responsibility of the judiciary to the public.

\section{Suggestion}

In order to maximize judicial authority implementation in Supreme Court (MA) and in order to compensate the reputation of Constitutional Court (MK) which is so good in handling cases of judicial review, presumably Supreme Court (MA) can make corrections as a whole, both improvements on regulation or structure and process related to judicial review case handling. Through the improvement, it is believed that Supreme Court (MA) reputation will increase positively by the public, especially for those who seek justice through judicial review in Supreme court (MA), and Supreme Court (MA) can balance the reputation of Constitutional Court and in turn will create positive legal culture for the existence of Supreme Court (MA) itself.

\section{References}

Alec Stone Sweet. "The Politics of Constitutional Review in France and Europe". International Journal of Constitutional Law. Vol. 5 No. 1. January 2007. Oxford: Ox- 
ford University Press and New York University School of Law;

Harel, Alon and Tsvi Kahana. "The Easy Core Case for Judicial Review". Journal of Legal Analysis. Vol. 2 No. 1. Spring 2010. Oxford: Oxford University Press;

Law, David S. "A Theory of Judicial Power and Judicial Review". The Georgetown Law Journal. Vol. 97. 2009. Washington DC: Georgetown Law;

Mahkamah Agung Republik Indonesia.2014. Laporan Tahunan MA RI 2014. Jakarta: Mahkamah Agung Republik Indonesia;

MK RI. "Rekapitulasi Perkara Pengujian UndangUndang". http://www.mahkamahkonstitu si.go.id/index.php?page=web. RekapPUU\& menu=5. accessed on June 20, 2016.

Nasihuddin, Abdul Azis. "Implementasi Hak Uji Materiil Peraturan Daerah Kabupaten/ Kota oleh Mahkamah Agung dan Pengaruhnya Terhadap Pemberdayaan Daerah". Jurnal Dinamika Hukum. Vol. 13 No. 3. September 2013. Purwokerto: Faculty of Law Universitas Jenderal Soedirman;

Simamora, Janpatar. "Tafsir Makna Negara Hukum dalam Perspektif Undang-Undang Dasar Negara Republik Indonesia Tahun 1945". Jurnal Dinamika Hukum. Vol. 14 No. 3. September 2014. Purwokerto: Faculty of Law Universitas Jen-deral Soedirman.

"Comparison of Constitutional Court Authority Between Indonesia and South Korea". Jurnal Dinamika Hukum. Vol. 15 No. 3. September 2015. Purwokerto: Faculty of Law Universitas Jenderal Soedirman;

-.-.-.. "Considering Centralization Of Judicial Review Authority In Indonesia Constitutional System". IOSR Journal of Humanities And Social Science (IOSR-JHSS). Shastri Nagar. Ghaziabad. UP. Vol. 21 Issue 2. Ver. V (Feb. 2016). India: International Organization of Scientific Research;

Street, Amy. 2013. Judicial Review and the Rule of Law: Who is in Control?. London: The Constitution Society;

Treanor, William Michael. "Judicial Review Before Marbury". Stanford Law Review. Vol. 58. November 2005. Stanford. CA: The Stanford Law School;

Uzman, J. T Barkhuysen \& ML van Emmerik. "The Dutch Supreme Court: A Reluctant Positive Legislator?". Electronic Journal of Comparative Law. Vol. 14 Issue 3. De- cember 2010. The Netherlands: the Law Faculties of Maastricht. Tilburg and Utrecht;

Wise, Michael B.. "Judicial Review and Its Politicization in Central America: Guatemala. Costa Rica and Constitutional Limits on Presidential Candidates". Santa Clara Journal of International Law. Vol. 7 Issue 2. 2010. Santa Clara: School of Law Santa Clara University. 